\title{
POSSIBLE RAPID METHOD FOR THE DETERMINATION OF CONCRETE FROST RESISTANCE
}

\author{
Olga Pertceva ${ }^{1}$, Sergey Nikolskiy ${ }^{2}$ \\ ${ }^{1}$ Department of Unique Buildings and Constructions, Faculty of Civil Engineering, St. Petersburg Politechnical \\ University, Politechnicheskaya Str. 29, 195251 St. Petersburg, Russia \\ 2Department of Construction Designs and Materials, St. Petersburg Politechnical University, Politechnicheskaya \\ Str. 29, 195251 St. Petersburg, Russia \\ E-mail:1'olya_perceva@mail.ru(correspondingauthor)
}

\begin{abstract}
Main purpose of the present research is creating a new rapid method for the determination of frost resistance of concrete that is characterized by small labor input, high efficiency and a wide scope. During this research, the theoretical analysis of the dependence of frost resistance of a sample of concrete and the energy, which is emitted by a sample at destruction, was carried out. The offered method includes measurement of residual deformation of a sample after one cycle of freezing-defrosting, measurement of long strength and measurement of short-term strength. Based on the experimental data, calculation of the energy emitted by a sample after one cycle of freezing-defrosting, and the emitted energy necessary for relative decreasing in strength of a sample by $15 \%$ is carried out. Frost resistance of a sample is expressed as a mathematical relation of these energies, and the frost resistance of concrete is calculated as arithmetic mean on samples. The offered method does not demand long tests, it has high efficiency and wide scope, but special laboratory equipment is necessary.
\end{abstract}

Keywords: Frost resistance, concrete, long-term strength, dilatometric method, non-destructive loading, acoustic issue, relative tension set, durability of concrete

\section{Existing methods of determination of frost resistance of concrete}

Despite a variety of modern construction materials and technological researches in this area, concrete remains a more convenient material. It is a multipurpose and widespread material used at construction of buildings and facilities. The most important properties of concrete, defined at design of objects, are concrete's durability on compression/stretching, waterproofing and frost resistance. In the climatic conditions of northern latitudes where the North Western Region is situated, the last property is the most important.

Frost resistance of concrete is the ability of watersaturated concrete sample to maintain repeated standard thermo cycles without noticeable damage. If water filling concrete pores turns into ice, it will increase in volume and cause micro cracks in the concrete. When the number of freezing-defrosting cycles increases, damages of concrete accumulate, and its durability decreases. Different types of water pressure also cause frost deterioration of concrete, such as hydraulic and osmotic pressure (Rønning T.F. 2001), capillary pressure (Davie C. T., Pearce C. J., Bićanić N. 2005) and other types of water influence according to the existing theory of frost resistance (Gorchakov G.I., Kapkin M. M., Skramtaev B.G. 1965). For determining the concrete mix composition it is necessary to take into account frost resistance.

In worldwide experience there are some test methods to determine the durability of concrete to frost damage, such as Slab test (Swedish Standard 2005), CDF (RILEM Technical Committee TDC, 1996,), CIF-Test (RILEM Technical Committee TDC, 2004) and Cube-Test (Bunke, N. 1991). These test methods contain the following steps: curing and preparing the samples, presaturation of the samples and their thermo cycling. The test liquid simulates a deicing agent and contains $3 \%$ by weight of $\mathrm{NaCl}$ and $97 \%$ by weight of (demineralized) water in case of the test for the freeze-thaw and deicing salt resistance and demineralized water to test the freezethaw resistance of concrete respectively. Scaling of the samples is measured after a well defined number of freeze-thaw cycles and leads to an estimate of the resistance of the tested concrete against frost damage. However, the test methods differ in their procedures and conditions. CIF test also implies determination of internal damage by measuring of the relative dynamic modulus of elasticity (taking into account ultrasonic transit time) (Gehlen C. 2011).

Two different standard types of methods to determine frost resistance of concrete are used in the Russian Federation - basic and rapid.

Basic methods (Interstate Council for Standardization, Metrology and Certification 1995b) include production and test of samples by series. Further, all samples are satiated with water and a part of samples are subjected to repeated freezing and defrosting. After that all samples are destroyed by compression. For comparison of average values of strength, both types of samples are taken: tested with freezing-defrosting, and not tested. The next step is to define relative decrease in strength of material under different number of term cycles. Frost resistance of concrete is defined by the number of thermo cycles, which are necessary for decreasing in strength within limits stipulated by the standard.

During the estimation of frost resistance of concrete considerable random dispersion of values of concrete strength (variation coefficient $\rho=15 \ldots 20 \%$ ) (Interstate Council for Standardization, Metrology and Certification 1990) under invariable conditions of production and tests of samples gives rise to a wide scatter of average values of strength and demands large volume tests (quantity of test pieces $25 \ldots 50$ ) as proof that relative decrease in 
strength of $\Delta R / R=0.05 \ldots 0,15$ is a result of freezingdefrosting.

Therefore, the basic methods have two main weaknesses: high labour input and small operability. Determination of frost resistance by basic methods takes big time intervals (from 1 to 6 months), so the rapid methods are necessary.

One of the existing rapid methods is a "Dilatometric rapid method for the determination of frost resistance" (Interstate Council for Standardization, Metrology and Certification 1995c). This method is a prototype for the method, which has been offered by the author. Dilatometric rapid method for the determination of frost resistance includes production of concrete samples, measurement of samples, determination of initial volume, saturation of samples by water, simultaneous freezing of each sample sated with water and a standard sample in the dilatometer up to the standard temperature and their measurement, thus the differences of values of volume deformations of the concrete and standard samples (relative changing of volume) are determined. Frost resistance of concrete is established by the maximum relative difference of volume deformations of the concrete and standard samples in accordance with the tables provided in standard specification (Interstate Council for Standardization, Metrology and Certification 1995) taking into account the type of concrete, the form and size of the samples.

However, the results from the tables provided in the state standard specifications are acceptable only for concrete based on Portland cement and slag Portland cement without surface-active additives (PEAHENS), such concretes are used extremely seldom now. To obtain new tables long labour-consuming experiments using the basic methods are needed (Dikun A.D. at al. 2003, 2004, 2005).

The task of the project is development of the methods for rapid definition of frost resistance of concrete, decreasing labour input and increasing operability.

\section{The suggested method of determination of frost resistance of concrete}

Suppositive solution belongs to test methods of porous water-saturated bodies and is intended for the testing of the brand of concrete for frost resistance. It involves the number of standard cycles of freezing-defrosting (for example, from +20 to $-18 \pm 2^{\circ} \mathrm{C}$ for 4 hours), necessary for decreasing of strength of the samples sated with water, at a size stipulated by the standard specification, in particular, for 5 or $15 \%$, i.e. relative decreasing in strength of $\Delta \mathrm{R} / \mathrm{R}=0.05 \ldots 0.15$.

The main goal has been reached like in the prototype by production of the series of samples from concrete mix, satiation of the samples with water, measuring of the samples, and freezing up to the standard temperature. However, in contrast to a prototype the following actions should be performed:

- Long-term strength of each sample in the conditions of stretching should be previously defined by nondestructive testing;
- Refreezing of the samples and establishing the relative tension set of each sample;

- Determination of the energy per unit of sample volume, disseminated in the course of freezingdefrosting, by values of relative tension set and a long-term strength in the conditions of stretching of a sample;

- Loading of each sample in the conditions of monoaxial compression to the extreme loading corresponding to short-term strength;

- Registration of the values of axial loading and axial strain of each sample corresponding to them;

- Definition of the energy per unit of sample volume disseminated in the course of its compression to extreme loading by the received values of axial loading and axial strain of each sample corresponding to them;

- Estimation of the value of frost resistance of the concrete sample, as the value proportional to the relation of energy, disseminated in the course of compression to extreme loading, to the energy disseminated in the course of freezing-defrosting;

- Determination of frost resistance of a concrete brand as arithmetic-mean value of the tested brands of concrete samples by frost resistance.

Long-term strength of the sample in the conditions of stretching corresponds to irreversible development of cracks in a concrete sample. Definition of the relative tension set and long-term strength of a sample allows estimating the energy disseminated in the process of destruction per unit of volume of material in the course of freezing-defrosting as per formula:

$W_{t c}=\theta_{r e l} R_{l t}$,

where:

$\mathrm{W}_{\mathrm{tc}}$-energy per unit of sample volume disseminated in the course of freezing-defrosting;

$\Theta_{\text {ten }}$ - relative tension set of a sample;

$\mathrm{R}_{\mathrm{It}}$ - long-time strength of the sample in the conditions of stretching;

$\mathrm{R}_{\mathrm{lt}}$ is calculated by relating greatest non-destructive loading in the conditions of stretching $\mathrm{L}_{0}$, which is determined by experiment. Longevity of concrete takes infinite value without outreaching $\mathrm{L}_{0}$.

Nowadays, the concept of greatest non-destructive loading $\mathrm{L}_{0}$ is usefully employed for express-monitoring of different kinds of long-term resistance, such as durability (mechanical (Nikolskaya T.S., Nikolskiy S.G. 2007b) and exegetical (Nikolskaya T.S., Nikolskiy S.G. 2008a, 2008b )), the remaining life of product (Nikolskaya T. S., Nikolskiy S. G. 2009a, 2009b), longevity (Nikolskaya T.S., Nikolskiy S.G. 2009d; Nikolskaya T.S. 2002, 2009), frost resistance (Akimov S. V., Nikolskaya T. S., Nikolskiy S. G. 2009, 2010; Nikolskiy S. G., Vorontcova E. A. 2012), cracking resistance (Nikolskaya T.S., Nikolskiy S. G. 2007a), erosion behaviour (Nikolskaya T. S., Nikolskiy S. G. 2009c; Nikolskiy S. G. 2008), corrosion (Barabanthikov U. G. at al. 2012) and time-dependent deformation (Belyaeva S. V. at al. 2012). 
In the time of freezing, the development of concrete damages is explained by subcritical crack growth. In the brittle solids cracks begin to take off by shearing action (Nikolskiy S.G. 2009), the speed of their development is no more than $10-4 \mathrm{~m} / \mathrm{s}$ (Nikolskiy S.G. 1990, 2008). Therefore, in the conditions of freezing, water filled crack in concrete capture of the nearby closed pores. It stabilizes the pressure in the water filled crack about the value causing in a material stretching tension, equal to long-term strength of a sample in the conditions of stretching.

(Nikolskiy S.G. 2008; Nikolskaya T.S., Nikolskiy S.G. 2001) If temperature body change from $78 \mathrm{~K}$ to $1493 \mathrm{~K}$ and loading is as described earlier, value L0 shifts inside of deviation determination of it, i.e. $1 \div 3 \%$. This fact permits to use value $\mathrm{L}_{0}$ received at a low temperature, when energy per unit of sample volume disseminated in the course of freezing-defrosting is established.

Sample loading in the conditions of monoaxial compression to extreme loading, registration of these values of axial loading and axial strain, corresponding to the loads, allow calculating energy per unit of sample volume disseminated in the course of its compression to extreme loading by numerical integration of dependence of axial loading from axial strain. Value of the energy disseminated in the unit of volume of a sample in the course of its compression to extreme loading, in proportion to a square of short-term strength (Ahverdev I.N. 1981):

$W_{\text {com }}=\alpha R^{2}$,

where:

$\mathrm{W}_{\text {com }}$-energy per unit of sample volume disseminated in the course of its compression to extreme loading;

$\mathrm{R}$ - short-term strength;

$\alpha$ - proportionality coefficient.

The logarithmation of expression (2) and the subsequent differentiation introduce the dependence between relative decreasing in the energy disseminated per unit of volume of a sample in the course of its compression to extreme loading and relative decreasing in short-term strength:

$\frac{\Delta W}{W_{\text {com }}}=2 \frac{\Delta R}{R}$

where:

$\mathrm{W}_{\text {com }}$ - energy per unit of sample volume disseminated in the course of its compression to extreme loading;

$\Delta \mathrm{W}$ - absolute change of energy disseminated in unit of volume of a sample in the course of its compression;

$\mathrm{R}$ - short-term strength;

$\Delta \mathrm{R}$ - absolute change of short-term strength;

Formula (3) allows passing from relative decreasing in short-term strength allowed by the standard for concrete to admissible for the studied sample to relative decreasing in the energy $[\Delta \mathrm{W}]$ disseminated per unit of volume of a sample:

$[\Delta W]=2 W_{\text {com }}\left[\frac{\Delta R}{R}\right]$ where:

$\mathrm{W}_{\text {com }}$ - energy per unit of sample volume disseminated in the course of its compression to extreme loading;

$\Delta \mathrm{W}$ - absolute change of energy per unit of sample volume disseminated in the course of its compression to extreme loading;

$\mathrm{R}$ - short-term strength;

$\Delta \mathrm{R}$ - absolute change of short-term strength;

$\left[\frac{\Delta R}{R}\right]$ - standard relative decrease in strength

$[\Delta W]$ - standard absolute change of energy per unit of sample volume disseminated in the course of its compression to extreme loading.

Thus, frost resistance as the number of freezingdefrosting cycles will be defined by the relation between admissible absolute change of the energy per unit of volume of a sample disseminated in the course of compression and energy per unit of sample volume disseminated in the course of freezing-defrosting, i.e. as per formula:

$F_{\text {sam }}=\frac{[\Delta W]}{W_{t c}}$

where:

$[\Delta W]$ - standard absolute change of energy per unit of sample volume disseminated in the course of its compression;

$\Delta \mathrm{W}$ - absolute change of energy per unit of sample volume disseminated in the course of its compression;

$\mathrm{W}_{\mathrm{tc}}$-energy per unit of sample volume disseminated in the course of freezing-defrosting;

$\mathrm{F}_{\text {sam }}$ - frost resistance of the concrete sample;

\section{Realization of the suggested method}

The method is realized as follows. First of all, samples are made in the form of cylinders or cubes with an edge of $10 \mathrm{~cm}$ from concrete mix of the demanded composition. After curing the samples are sated with water and measured. Further greatest non-destructive loading of $\mathrm{L}_{0}$ is defined for each sample by a nondestructive testing, for example, a method of acoustic emission (Nikolskaya T. S., Nikolskiy S. G., Terentiev V. P. 2009). Without outreaching $\mathrm{L}_{0}$ a sample crack does not develop yet in the conditions of stretching. Expedient stretching tension in cylinders or cubes is created compressing them along the lines of contact of cylinders with the plane (splitting). If $\mathrm{L}_{0}$ is determined, it is possible to calculate the limit of durability for the tested sample:

$R_{l t}=2 \frac{L_{0}}{\pi S}$

where:

$\mathrm{S}$ - area of the section of the sample, perpendicular to compression planes;

$\mathrm{L}_{0}$ - the greatest non-destructive loading of the sample in the conditions of stretching;

$\mathrm{R}_{\mathrm{lt}}$-long-term strength of the sample in the conditions of stretching.

After freezing-defrosting of the sample up to the standard temperatures and definition of the relative tension set of 
the sample it is possible to calculate the energy per unit of sample volume disseminated in the course of its freezingdefrosting as per formula (1).

Further, the sample is squeezed in the conditions of monoaxial compression to extreme loading, and the current values of axial loading and relative tension set of the sample corresponding to them are registered. Numerical integration of dependence of axial loading on absolute relative tension set of the sample and distribution of its result on the volume of the sample allows calculating the energy per unit of volume of the material disseminated before the achievement of extreme loading. Frost resistance of a concrete sample $F_{\text {sam }}$ is calculated by the received results as per formula:

$$
F_{\text {sam }}=2\left[\frac{\Delta R}{R}\right] \cdot \frac{W_{\text {com }}}{W_{t c}}
$$

where:

$\mathrm{W}_{\text {com }}$ - energy per unit of sample volume disseminated in the course of its compression to extreme loading;

$\mathrm{R}$ - short-term strength;

$\Delta \mathrm{R}$ - absolute change of short-term strength;

$\left[\frac{\Delta R}{R}\right]$ - standard relative decrease in strength;

$\mathrm{W}_{\mathrm{tc}}$-energy per unit of sample volume disseminated in the course of freezing-defrosting.

Frost resistance of concrete is found as an average of values of frost resistance of samples. Confidential interval of concrete's frost resistance is counted on dispersion of values of frost resistance for a series of samples.

This method was realized on 10 samples cubes $10 \mathrm{~cm}$ on edge at the age of 88 days made of a concrete mix of the following composition: Brand 400-1 Portland cement weight part, sand -2 weight parts, granite rubble $5 \ldots 20 \mathrm{~mm}-4.5$ weight parts, water -0.6 weight parts. It has been experimentally established in two different ways for this type of concrete at the age of 88 days that after 105 cycles of freezing-defrosting corresponding to the frost resistance durability of the brand of this concrete, average relative decrease in strength makes 0.142 as per way (Nikolskiy S.G. 2008) and 0.16 as per basic way (Interstate Council for Standardization, Metrology and Certification 1995b), that is, both values lie within an error of the methods used. On the average, relative decrease in strength is $15 \%$.

Samples were sated with water according to the item state standard specification, their volume was measured and registered. For each cube sated with water splitting according to the item value of the greatest nondestructive loading (without that excess of a crack in a sample don't develop) was defined. After each test the plane of compression of the sample was changed for the plane perpendicular to previous compression. Definition of the greatest non-destructive loading carried out by means of an acoustic emission way, using AF-15 AEcomplex of Kishenevskiy Manufacturer. Acoustic sensors with a frequency of $20-200 \mathrm{kHz}$ were installed on the verge of the sample, parallel to the plane of compression. For creation of axial loading a hydraulic press was used. Considering the value of the greatest non-destructive loading, the corresponding value of long-term strength of the sample in the conditions of stretching was calculated. Then the average value of long-term strength was calculated too. The results of calculation are given in the table.

Water-saturated samples were placed in the measuring camera of the differential volume dilatometer DOD-100-K, and a standard aluminum sample was placed in the second camera. Both cameras were filled with kerosene and pressurized. The dilatometer with samples was installed in the freezer freezing with a speed $0.3^{\circ} \mathrm{C} / \mathrm{min}$ before the achievement of temperature $(-18 \pm 2)^{\circ} \mathrm{C}$ was began. According to the dependency diagrams of differences, relative volume tension set of the concrete and aluminum sample was calculated. Energy per unit of sample volume disseminated in the course of its freezingdefrosting was calculated as per formula (1) for each sample.

Further average value of the long-term strength of the sample in the conditions of stretching was defined as an average $\mathrm{R}_{\mathrm{lt}}$ values long-term strength in the conditions of stretching.

Axial compression of samples with a speed of $400 \mathrm{~kg} / \mathrm{sec}$. was carried out on the hydraulic press equipped with the graph plotter of dependence of axial loading from axial strain. Values on a dynamometer are determined by the location of the conducted and conducting arrows being part of the closed electronic chain with a control bulb. Removal of sample loading was begun on a signal of the control bulb, which is switched off by electro contacts on the conducted and conducting arrow of the dynamometer. The conducted arrow of the dynamometer press registered the value of the maximum loading. By the dependence received on the graph plotter the area under it was determined, i.e. received energy disseminated per volume of a sample in the course of its compression to extreme loading. Energy per unit of sample volume disseminated in the course of its compression to extreme loading was calculated as per formula (8):

$W_{\text {com }}=\frac{W}{V}$

where:

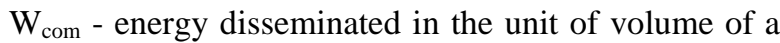
sample in the course of its compression to extreme loading;

$\mathrm{W}$ - energy disseminated in the sample in the course of its compression to extreme loading;

$\mathrm{V}$ - sample volume.

Then for each sample brand of concrete frost resistance was calculated (Table 1) as the number of freezingdefrosting cycles necessary for decrease in its strength by $15 \%$ as per formula (7).

Further, an average $\bar{F}_{15}$ for values of $\mathrm{F}_{15 \mathrm{i}}$, and an average square deviation of the results of the experiment were calculated:

$S=\sqrt{\frac{\left(F_{15 i}-\bar{F}_{15}\right)^{2}}{9}}$ 
where:

$\mathrm{S}$-average square deviation of the results of the experiment;

$\mathrm{F}_{15 \mathrm{i}}$ - the value of concrete i-sample frost resistance at decreasing of the short-term strength of the sample in the conditions of compression for $15 \%$, received by the offered method; where $\mathrm{i}$ is changed from 1 to 10 ;

$\overline{F_{15}}$-frost resistance of concrete, equal to arithmeticmean value of frost resistance for series of concrete samples at decreasing their short-term strength in the conditions of compression by $15 \%$.

The average square deviation of $F_{15 i}$ values was equal to 16. Taking that into account, a divergence of average value of frost resistance is equal 99.7 and the earlier experimentally found number of cycles 105 (F15 brand) necessary for decreasing $\mathrm{R}$ by $15 \%$, it is possible to consider casual, and the offered method is valid.

Table 1. Definition type concrete's frost resistance as per offered method

\begin{tabular}{|c|c|c|c|c|c|c|}
\hline № & $\begin{array}{c}\bar{R}_{\text {lt }} \\
\mathrm{MPa}\end{array}$ & $\begin{array}{c}\Theta_{\text {ten }} \\
\cdot 10^{4}\end{array}$ & $\begin{array}{c}\mathrm{W}_{\text {tc }} \\
\cdot 10^{4} \\
\mathrm{MPa}\end{array}$ & $\begin{array}{c}\mathrm{W}_{\text {com }} \cdot 10, \\
\mathrm{MPa}\end{array}$ & $\begin{array}{c}{[\Delta \mathrm{W}]} \\
\cdot 10^{2}, \\
\mathrm{MPa}\end{array}$ & $\mathrm{F}_{15 \mathrm{i}}$ \\
\hline 1 & 1.5 & 2.7 & 4.05 & 0.9990 & 2.997 & 74 \\
\hline 2 & 1.7 & 3.1 & 5.27 & 1.7215 & 5.165 & 98 \\
\hline 3 & 1.8 & 1.8 & 3.24 & 1.2312 & 3.694 & 114 \\
\hline 4 & 1.9 & 2.6 & 4.90 & 1.6796 & 5.039 & 102 \\
\hline 5 & 2.0 & 2.5 & 5.00 & 1.4333 & 4.300 & 86 \\
\hline 6 & 2.1 & 1.9 & 4.00 & 1.4364 & 4.309 & 108 \\
\hline 7 & 2.2 & 2.6 & 5.72 & 2.2308 & 6.692 & 117 \\
\hline 8 & 2,3 & 2,1 & 4,83 & 1,3846 & 4,154 & 86 \\
\hline 9 & 2,9 & 1,8 & 5,22 & 1,6008 & 4,802 & 92 \\
\hline 10 & 3,1 & 1,5 & 4,65 & 1,8600 & 0,558 & 120 \\
\hline Average & 2,15 & 2,1 & 4,69 & 1,5577 & & 99,7 \\
\hline
\end{tabular}

\section{Conclusions}

The offered method expands a list of technical means for the rapid definition of frost resistance of concrete. Duration of determination of frost resistance is caused by the time of sample water saturation (4 days according to standard specification (Interstate Council for Standardization, Metrology and Certification 1995a)). At present, there is a pending patent application for the method suggested (Nikolskiy S.G., Pertceva O.N. 2013). Detailed research and pilot studies are necessary to get more data that are experimental and create new method of determination of frost resistance in future.

\section{References}

Ahverdev, I.N., 1981. Osnovy fiziki betona. Strojizdat, Moscow. p. 425.

Akimov, S.V.; Nikolskaya, T.S.; Nikolskiy, S.G., 2010. Sposob opredelenija morozostojkosti kamnja. RU Patent 2380681.

Akimov, S.V.; Nikolskaya, T.S.; Nikolskiy, S.G., 2009. Obrazec dlja szhatija kamnja pri ocenke ego morozostojkosti. RU Patent 2370767.

Barabanthikov, U.G. et al., 2012. Sposob ocenki stojkosti izdelij pri nagruzhenii, RU Patent 2442134.
Belyaeva, S.V. et al., 2012. Sposob ocenki korrozionnoj stojkosti betonnyh izdelij. RU Patent 2449266.

Bunke, N., 1991. Prüfung von Beton - Empfehlungen und Hinweise als Ergänzung zu DIN 1048. Schriftenreihe des Deutschen Ausschusses für Stahlbeton, 422, pp. 12-15. Russia.

Davie, C.T.; Pearce, C.J.; Bićanić, N., 2005. Effects of Fluid Transport on the Structural Integrity of Concrete Nuclear Pressure Vessels. Proceeding of the 13 ACME conference: University of Sheffield, 21-22 march, UK.

Dikun, A.D. et.al., 2005. Opyt jekspressnogo opredelenija morozostojkosti betona transportnyh sooruzhenij. Stroitel'nye materialy, 8, pp. 55-56.

Dikun, A.D. et.al., 2004. Razvitie otechestvennogo dilatometricheskogo metoda prognozirovanija svojstv betona, Stroitel'nye materialy, 4, pp. 52-56.

Dikun, A.D. et al., 2003. Prognozirovanie morozostojkosti betona. Stroitel'nye materialy, 11, pp. 28-30.

Interstate Council for Standardization, Metrology and Certification 1995a, Concretes. Methods for the determinationof frost-resistance.General requirements, GOST 10060.0-95, Interstate Council for Standardization, Metrology and Certification, Russia.

Interstate Council for Standardization, Metrology and Certification 1995b. Concretes. Basic method for the determination of frost-resistance. GOST 10060.1-95, Interstate Council for Standardization, Metrology and Certification, Russia.

Interstate Council for Standardization, Metrology and Certification 1995c. Concretes. Dilatometric rapid method for the determination of frost-resistance, GOST 10060.3-95. Interstate Council for Standardization, Metrology and Certification, Russia.

Interstate Council for Standardization, Metrology and Certification 1990. Concretes. Methods for strength determinationusing reference specimens, GOST 10180-90, Interstate Council for Standardization, Metrology and Certification, Russia.

Gehlen, C., 2011. Compilation of Test Methods to Determine Durability of concrete. Critical review RILEM Technical Committee TDC, $11 \mathrm{p}$.

Gorchakov, G.I.; Kapkin, M.M.; Skramtaev, B.G., 1965. Povyshenie morozostojkosti betona $v$ konstrukcijah promyshlennyh i gidrotehnicheskih sooruzhenij. Strojizdat, Russia, 195 p.

Nikolskaya T.S. 2009, Ispol'zovanie akusticheskoj jemissii dlja prognozirovanija dolgovechnosti izdelija. Proceeding of the IV international conference "Problemy prognozirovanija nadezhnosti $i$ dolgovechnosti”, pp. 14-17 October, 2009, St. Petersburg, Russia.

Nikolskaya, T.S., 2002. Particularities of Acoustic Emission in Ceramic Product under Partial Uploading. Problems of Strength, 1, pp. 140-147.

Nikolskaya, T.S.; Nikolskiy, S.G., 2013. Akusto-jemissionnyj jekspress-kontrol' dlitel'noj stojkosti materialov. Study guide, publishing office of Sankt-Petersburg Politechnical University, St. Petersburg.

Nikolskaya, T.S.; Nikolskiy, S.G., 2009a. Sposob opredelenija ostatochnogo resursa izdelija. RU Patent 2348917.

Nikolskaya, T.S.; Nikolskiy, S.G., 2009b. Sposob opredelenija ostatochnogo resursa stal'nogo zheleznodorozhnogo rigelja, RU Patent 2366939.

Nikolskaya, T.S.; Nikolskiy, S.G., 2009c. Sposob ocenki stojkosti hrupkogo materiala protiv jerozii, RU Patent 2348026. 
Nikolskaya, T.S.; Nikolskiy, S.G., 2009d. Sposob opredelenija dolgovechnosti izdelija iz hrupkogo materiala. RU Patent 2359244.

Nikolskaya, T.S.; Nikolskiy, S.G., 2008a. Sposob kontrolja dlitel'noj prochnosti jelektroprovodjashhego izdelija. RU Patent 2395993.

Nikolskaya, T.S.; Nikolskiy, S.G., 2008b. Sposob opredelenija jelektricheskoj prochnosti polimernoj izoljacii, RU Patent 2333504.

Nikolskaya, T.S.; Nikolskiy, S.G., 2008c. Akusticheskaja jemissija pri jerozii melkozernistogo betona. Nauchnotehnicheskie vedomosti SPBGPU, 4, pp. 242-248.

Nikolskaya, T.S.; Nikolskiy, S.G., 2007a. Akustojemissionnyj sposob kontrolja jelektroprovodjashhego izdelija. RU Patent 2315993.

Nikolskaya, T.S.; Nikolskiy, S.G., 2007b. Sposob kontrolja prochnosti izdelija iz hrupkogo materiala. RU Patent 2305281.

Nikolskaya, T.S.; Nikolskiy, S.G., 2001. Vlijanie temperatury na porogovye parametry prochnosti keramiki. SanktPeterburgskij zhurnal jelektroniki, 4, pp. 140-147.

Nikolskaya, T.S.; Nikolskiy, S.G.; Terentiev, V.P., 2009. Jekspress-metody ocenki dlitel'noj stojkosti betona. Proceeding of the III international conference "Populjarnoe betonovedenie”, 27 February-2 March, 2009, St. Petersburg, Russia.

Nikolskiy, S.G., 2009. Fracture Surface Analysis of Ceramic Bare under Short- and Long-term Bending. Problems of Strength, 5, pp. 133-140.
Nikolskiy, S.G., 2008. Jekspress-kontrol' jerozii betona. Inzhenerno-stroitel'nyj zhurnal, 2, pp. 39-44.

Nikolskiy, S.G., 1990. Acoustic emission control of strength. Problems of Strength, 6, pp. 102-106.

Nikolskiy, S.G.; Vorontcova, E.A., 2012. Sposob opredelenija vodocementnogo otnoshenija betona po trebuemoj morozostojkosti pri proektirovanii. $R U$ application for $a$ patient since, May, 2012 with favourable conclusion.

Nikolskiy, S.G.; Pertseva, O.N., 2013. Sposob opredelenija marki betona po morozostojkosti. RU application for a patient No. 2013125870 since 4 July, 2013.

RILEM Technical Committee TDC, 2004. CIF Test, Test Method of frost resistance of concrete. RILEM TC 176 Recommendation, Germany.

RILEM Technical Committee TDC, 1996. CDF Test, Test Method for the Freeze-Thaw-Resistance of concrete with sodium chloride solution. RILEM TC 117-FDC Recommendation, Germany.

Rønning, T.F., 2001. Freeze-Thaw Resistance of Concrete Effect of: Curing Conditions, Moisture Exchange and Materials. Thesis for the dr. degree, Norwegian Institute of Technology, Norway, $416 \mathrm{p}$.

Swedish Standard 2005. Concrete testing - Hardened ConcreteFrost Resistance. SS 137244, Sweden. 